\title{
The Effects of Dodecyl Maltoside and Sodium Dodecyl Sulfate Surfactants on the Stability and Aggregation of Recombinant Interferon Beta-1b
}

\author{
Mohadeseh Haji Abdolvahab, ${ }_{1}$ Ahmad Fazeli, ${ }^{2}$ Mohammad Reza Fazeli, ${ }^{3}$ \\ Vera Brinks, and Huub Schellekens ${ }^{1}$
}

Aggregation often occurs during manufacturing and storage of protein drugs. Detergents such as sodium dodecyl sulfate are commonly used to prevent aggregation but need to be eliminated before final formulation for safety reasons. We studied the ability of dodecylmaltoside (DDM), a nontoxic alkyl saccharide surfactant, to reduce aggregation and increase the stability of interferon beta- $1 \mathrm{~b}$ (IFN)- $\beta-1 \mathrm{~b}$. An increase of $8^{\circ} \mathrm{C}$ in the $T_{m}$ of IFN- $\beta-1 \mathrm{~b}$ was observed when $0.1 \%$ of DDM was present in the protein solution. The absorption of DDM on hydrophobic surfaces of IFN- $\beta-1 b$ enables the surface to become hydrophilic and non-ionic, and increases the stability of the protein. $0.1 \% \mathrm{DDM}$ also results in a $62 \%$ increase in helical and a $25 \%$ decrease in $\beta$-sheet structures. $0.1 \%$ DDM not only suppresses aggregate formation but also improves IFN- $\beta-1 \mathrm{~b}$ solubilization. Furthermore, we have showed the protective effect of DDM on the anti-viral activity of IFN- $\beta-1 b$ in solution.

\section{Introduction}

$\mathrm{R}$ ECOMBINANT HUMAN INTERFERON BETA (rhIFN- $\beta$ ) is widely used to treat relapsing-remitting multiple sclerosis. There are 2 different IFN- $\beta$ product types in the market: IFN- $\beta$-1b (eg, Betaferon ${ }^{\circledR}$ and Extavia ${ }^{\circledR}$ ) and IFN- $\beta$-1a (eg, Avonex ${ }^{\circledR}$ and Rebif $\left.{ }^{(B)}\right)$. The products differ in various aspects such as formulation and route of administration. In addition, IFN- $\beta$-1b is produced in Escherichia coli and is non-glycosylated; whereas IFN- $\beta$-1a is produced in $\mathrm{CHO}$ cells and is glycosylated. IFN- $\beta$ - 1 a has the same amino-acid sequence as endogenous human IFN- $\beta$, while IFN- $\beta$-1b has its Cys-17 mutated to a serine and the N-terminal methionine is deleted. Furthermore, IFN- $\beta$-1b (Betaferon) contains $\sim 60 \%$ noncovalent aggregates and IFN- $\beta$ - 1 a (Avonex) contains mainly monomeric IFN- $\beta$ with a low percentage of non-covalent aggregates (Runkel and others 1998).

Many studies have shown that aggregates in rhIFN- $\beta$ products are a risk factor for immunogenicity (Schellekens 2002; Frokjaer and Otzen 2005; de Vries and others 2009; Wolbink and others 2009). Anti-rhIFN- $\beta$ antibodies have been shown to lower treatment efficacy.

Surfactants are widely used in pharmaceutical protein formulations to compete with protein for interfaces that might induce unfolding, aggregation, and precipitation of the protein. They hinder a broad range of physical instability phe- nomena such as protein-protein association, aggregation, and precipitation. Thus, they are essential components of many protein formulations (Maggio 2012).

Surfactants, or detergents, have been used not only to purify, isolate, or solubilize proteins, but also to maintain biological activity by binding to proteins through electrostatic and hydrophobic interactions (Subramanian and others 1986).

A detergent extensively used during protein purification is sodium dodecyl sulfate (SDS). SDS inhibits aggregate formation; however, it is a toxic surfactant and has been shown to irritate skin and eyes (Marrakchi and Maibach 2006), and it needs to be eliminated during formulation. However, its removal may lead to irreversible aggregation, protein precipitation, and greater production costs (Seddon and others 2004).

Non-ionic-ether-based surfactants show substantial improvements in the stability of proteins (Steinhardt and Reynolds 1969; Stubbs and others 1976; Maggio 2010; Rifkin and others 2011). A broad range of alkylsaccharides (non-ionic surfactants) has been studied as transmucosal absorption enhancers (Pillion and others 1994, 2002; Ahsan and others 2001). More recently, it was discovered that some of these molecules such as dodecylmaltoside (DDM) are highly effective in preventing aggregation (Rifkin and others 2011).

DDM, composed of a hydrophilic maltose and a hydrophobic alkyl chain, has been demonstrated to increase solubilization of diverse membrane proteins (Lopez and others

\footnotetext{
${ }^{1}$ Departments of Pharmaceutical Sciences and Innovation Studies, Utrecht University, Utrecht, The Netherlands.

${ }^{2}$ Biotechnology Group, Department of Chemical Engineering, Tarbiat Modares University, Tehran, Iran.

${ }^{3}$ Department of Drug and Food Control, Faculty of Pharmacy and Pharmaceutical Quality Assurance Research Center, Tehran University of Medical Sciences, Tehran, Iran.
} 
2002), to stabilize proteins during lyophilization and subsequent reconstitution (Maggio 2008), and, therefore, to lower aggregation. DDM is non-toxic, non-mutagenic, and non-irritating (Rossi 2005; Rifkin and others 2011) and it metabolizes into fatty acids and sugar after administration (Weber and Benning 1984; Rifkin and others 2011). DDM has been used in the formulation of peptide drugs such as eye-drops of insulin. The biodegradation of alkylglycosides to common products of body metabolism is a significant property for an absorption enhancer, which itself may be absorbed, and minimizes the systemic toxicity of this class of compounds (Pillion and others 1995). Moreover, DDM has been shown to improve the transport of insulin across epithelial monolayers without causing cell damage (Tirumalasetty and Eley 2005).

In this study, the ability of DDM to increase the stability of IFN- $\beta-1 b$ and reduce its aggregation was analyzed and compared with SDS using different physical and mathematical methods.

\section{Materials and Methods}

\section{Materials}

IFN- $\beta-1 b$ at a concentration of 330 and $150 \mu \mathrm{g} \mathrm{mL}^{-1}$ in $50 \mathrm{mM}$ sodium acetate buffer at $\mathrm{pH} 5.5$ was a kind gift from Zistdaru Danesh Co. Ltd. DDM was purchased from Thermo Fisher Scientific, and SDS was purchased from Sigma-Aldrich. Protein concentration was determined by UV absorbance measurements at a wavelength of $280 \mathrm{~nm}$ with an extinction coefficient of 1.58 .

\section{Visual inspection}

Samples were inspected visually against a dark background before further analysis with water as a control.

\section{UV spectroscopy}

UV spectra $(\lambda=240-370 \mathrm{~nm})$ were recorded automatically during every $5^{\circ} \mathrm{C}$ increase from $25^{\circ} \mathrm{C}$ to $70^{\circ} \mathrm{C}$ using an UV$2450 \mathrm{UV} / \mathrm{VIS}$ spectrophotometer in a 8-well quartz cuvette with a $1-\mathrm{cm}$ path length. Samples $\left(150 \mu \mathrm{g} \mathrm{mL}{ }^{-1}\right.$ IFN- $\left.\beta-1 b\right)$ containing $0.1 \%$ SDS or $0.01 \%, 0.1 \%$, or $0.5 \%$ DDM were analyzed. The corresponding sample buffer- $50 \mathrm{mM}$ sodium acetate buffer at pH 5.5-was used as a blank.

\section{Dynamic light scattering}

The average diameter (Z-ave) and polydispersity index (PDI) of the particles in each sample were obtained using dynamic light scattering (DLS). Samples $\left(330 \mu \mathrm{g} \mathrm{mL} \mathrm{m}^{-1}\right.$ IFN- $\beta$-1b) containing $0.1 \%$ SDS or $0.01 \%, 0.1 \%$, or $0.5 \%$ DDM were measured at a $90^{\circ}$ angle in a Malvern ALV CGS-3 goniometer (Malvern Instruments) that was equipped with a HeNe laser source $(\lambda) 632.8 \mathrm{~nm}, 22 \mathrm{~mW}$ output power. The DLS time correlation was analyzed with ALV Correlator 3.0 software (ALV).

\section{Fluorescence spectroscopy}

The tertiary structure of IFN- $\beta-1 b$ was analyzed with a Horiba Fluorolog fluorometer (Horiba Jobin Yvon). Samples were excited at $295 \mathrm{~nm}$, and the fluorescence emission spectra were measured between $25^{\circ} \mathrm{C}$ and $70^{\circ} \mathrm{C}$ from 307 to $450 \mathrm{~nm}$ in quartz cuvettes with a $1 \mathrm{~cm}$ path length. The slits were set at $5 \mathrm{~nm}$, and the average of 3 scans was used. The corresponding buffer spectra were deducted, and the emission maxima were determined using Siano software provided by Dr. A.O. Doroshenko (Kharkov, Ukraine). The program is based on an iterative nonlinear least-squares method based on the FletcherPowell algorithm. The individual emission bands were estimated using a lognormal function (Siano and Metzler 1969).

\section{Circular dichroism spectroscopy}

Circular dichroism (CD) was measured in a double beam DSM 1000 CD spectrometer (Online Instrument Systems) using a quartz cuvette with a $0.5-\mathrm{mm}$ path length (Hellma) at $25^{\circ} \mathrm{C}, 40^{\circ} \mathrm{C}$, and $70^{\circ} \mathrm{C}$. The secondary structure was expressed as molar differential extinction coefficient, ellipticity. Each spectrum was defined as the average of 3 repeated scans, and the background spectrum of the buffer was subtracted. Changes of elipticity at $222 \mathrm{~nm}$ were selected to analyze the opening up of helical regions in the protein structure (Kaushik and Bhat 2003). The method of Bohm and others employing CDNN CD Spectra Deconvolution Software (available 163 http://bioinformatik.biochemtech.unihalle.de/cdnn) was applied to quantify the structural changes.

\section{Thermodynamic calculations}

By assuming a 2-state refolding/unfolding mechanism under equilibrium conditions, the Gibb's free energy change, $\Delta G^{\circ}$, is referred to as the conformational stability of a protein (Fazeli and others 2013). If y is any observable parameter to follow unfolding (eg, fluorescence intensity or CD ellipticity), then

$$
y=\frac{y_{f}+y_{u} \cdot \exp \left\{-\Delta G^{\circ} / R T\right\}}{1+y_{u} \cdot \exp \left\{-\Delta G^{\circ} / R T\right\}}
$$

where $y_{f}$ and $y_{u}$ represent the values of $y$ for folded and unfolded protein, respectively, $R$ is the gas constant (1.987 cal $\mathrm{mol}^{-1} \mathrm{~K}^{-1}$ ), and $T$ is the absolute temperature $(\mathrm{K})$. A practical form of the Gibbs-Helmholtz equation for data fitting of proteins is given next:

$$
\Delta G^{\circ}(T)=\Delta H_{m}\left(1-T / T_{m}\right)-\Delta C_{p}\left[T_{m}-T+T \cdot \ln \left(T / T_{m}\right)\right]
$$

where $T_{m}$ is the melting temperature (at the midpoint of transition) as the reference temperature, $T$ refers to any temperature where $\Delta G^{\circ}(T)$ is calculated, and $\Delta H_{m}$ is the enthalpy of denaturation evaluated at the $T_{m}$. Therefore, equation 1 becomes

$$
y=\frac{y_{f}+y_{u} \cdot \exp \left\{-\left(\Delta H_{m}\left(1-T / T_{m}\right)-\Delta C_{p}\left[T_{m}-T+T \cdot \ln \left(T / T_{m}\right)\right]\right) / R T\right\}}{1+y_{u} \cdot \exp \left\{-\left(\Delta H_{m}\left(1-T / T_{m}\right)-\Delta C_{p}\left[T_{m}-T+T \cdot \ln \left(T / T_{m}\right)\right]\right) / R T\right\}}
$$


Marquardt-Levenberg routine as offered in Origin Pro v 8.5.1 software (Microcal, Inc.) was carried out for non-linear least-squares analysis to calculate thermodynamic parameters of IFN- $\beta-1 b$ under different solution conditions. For this purpose, equation 3 was used to fit experimental data until a fit coverage chi-square tolerance value of $1 \times 10^{-9}$ was reached.

\section{Antiviral activity}

The human lung carcinoma cell line (A549) and encephalomyocarditis virus were used to evaluate antiviral the activity of IFN- $\beta$-1b. Cytopathic effects were assessed by colorimetric changes using an ELISA reader (Bio-TEK Instruments, Inc.), and the bioactivity of IFN- $\beta-1 \mathrm{~b}$ was subsequently analyzed. Antiviral activities of IFN- $\beta$ - 1 b samples were determined by comparing their anti-cytopathic effect with that of the NIBSC IFN- $\beta$ Ser17 mutein standard (code: 00/574) in 3 replicates.

\section{Results}

\section{UV spectroscopy}

UV spectroscopy was used to determine the presence of aggregates. The optical density at $350 \mathrm{~nm}$ increases, and the ratio of 280/260 $\mathrm{nm}$ decreases in the presence of aggregates (Kueltzo and Middaugh 2005). Compared with IFN- $\beta-1 b$ in the absence of surfactant (which showed the highest OD350 $\mathrm{nm}$ values and the lowest OD280/260 $\mathrm{nm}$ ratios as the temperature increased from $25^{\circ} \mathrm{C}$ to $70^{\circ} \mathrm{C}$ (Fig. 1), most likely caused by extensive aggregation), samples in the presence of $0.1 \%$ DDM or $0.1 \%$ SDS showed low OD350 nm values and high OD280/260 $\mathrm{nm}$ ratios (Fig. 1). These data indicate an inhibition of aggregate formation in the presence of these surfactants.

\section{Dynamic light scattering}

Glycosylated IFN- $\beta$-1a is a cylindrical-shaped protein of roughly $2 \times 3 \times 4 \mathrm{~nm}$ (Karpusas and others 1997). IFN- $\beta$-1b in the absence of surfactant showed a large Z-ave at $25^{\circ} \mathrm{C}$, $40^{\circ} \mathrm{C}$, and $70^{\circ} \mathrm{C}(4,010,1,592$, and $4,508 \mathrm{~nm}$, respectively), indicating the presence of large aggregates independent of temperature (Table 1). The PDI of all samples decreased with increasing temperature, demonstrating a lower heterogeneity at higher temperatures.

The lowest Z-ave and PDI at $25^{\circ} \mathrm{C}$ was observed for IFN$\beta-1 b$ monomer samples in the presence of $0.1 \%$ DDM,
FIG. 1. UV absorption of interferon beta-1b (IFN- $\beta-1 b)$. (A) OD350 $\mathrm{nm}$ and (B) ratio between OD280/OD260 $\mathrm{nm}$ in the presence of dodecylmaltoside (DDM) or sodium dodecyl sulfate (SDS) when increasing the temperature from $25^{\circ} \mathrm{C}$ to $70^{\circ} \mathrm{C}$.
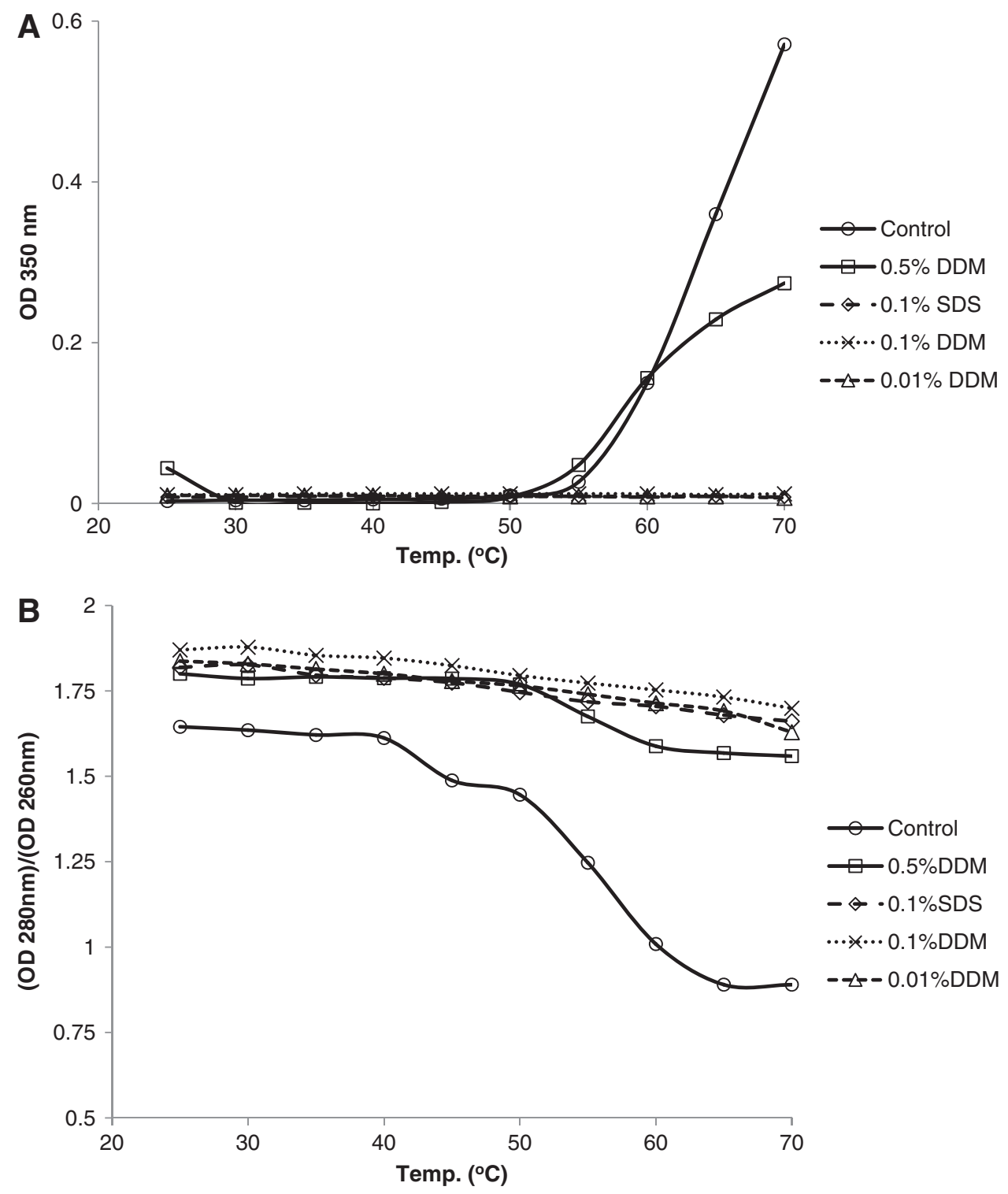
Table 1. Dynamic Light Scattering of Interferon Beta-1B in the Presence of Different Concentrations of Dodecylmaltoside or Sodium Dodecyl Sulfate at $25^{\circ} \mathrm{C}, 40^{\circ} \mathrm{C}$, and $70^{\circ} \mathrm{C}$

\begin{tabular}{|c|c|c|c|c|c|c|}
\hline \multirow[b]{2}{*}{ Temperature } & \multicolumn{2}{|c|}{$25^{\circ} \mathrm{C}$} & \multicolumn{2}{|c|}{$40^{\circ} \mathrm{C}$} & \multicolumn{2}{|c|}{$70^{\circ} \mathrm{C}$} \\
\hline & Z-ave (nm) & $P D I$ & Z-ave (nm) & $P D I^{*}$ & Z-ave (nm) & $P D I$ \\
\hline IFN without surfactant & 4,010 & 0.389 & 1,592 & 0.291 & 4,508 & 0.256 \\
\hline $\mathrm{IFN}+0.01 \% \mathrm{DDM}$ & 907 & 0.833 & 370 & 0.605 & 4,621 & 0.205 \\
\hline $\mathrm{IFN}+0.1 \% \mathrm{DDM}$ & 108 & 0.384 & 82 & 0.367 & 113 & 0.282 \\
\hline $\mathrm{IFN}+0.5 \% \mathrm{DDM}$ & 204 & 0.88 & 1,196 & 0.273 & 5,405 & 0.221 \\
\hline $\mathrm{IFN}+0.1 \% \mathrm{SDS}$ & 200 & 0.517 & 271 & 0.482 & 2,132 & 0.459 \\
\hline
\end{tabular}

DDM, dodecylmaltoside; IFN, interferon; PDI, polydispersity index; SDS, sodium dodecyl sulfate; Z-ave, average diameter.

indicating a smaller size and less heterogeneous particles (Demeester and others 2005; Philo 2009). The intense light scattering of the aggregates hinders the detection of the IFN$\beta-1 \mathrm{~b}$ monomer (Van Beers and others 2010) and elevated the Z-ave to 108,82 , and $113 \mathrm{~nm}$ at $25^{\circ} \mathrm{C}, 40^{\circ} \mathrm{C}$, and $70^{\circ} \mathrm{C}$, respectively (Table 1) compared with the size of the soluble IFN- $\beta$ - 1 a monomer at $2 \times 3 \times 4 \mathrm{~nm}$ (Karpusas and others 1997).

The addition of $0.1 \%$ SDS reduces protein aggregates, but it was not as effective as $0.1 \%$ DDM with IFN- $\beta-1 b$ (Table 1). At $25^{\circ} \mathrm{C}$, the $\mathrm{Z}$-ave decreased from $4,010 \mathrm{~nm}$ in the absence of surfactant to $200 \mathrm{~nm}$ with $0.1 \%$ SDS, and to $108 \mathrm{~nm}$ with $0.1 \%$ DDM. However, $0.1 \%$ SDS did not suppress aggregation at higher temperatures; thus, the size of the particles increased from $200 \mathrm{~nm}$ at $25^{\circ} \mathrm{C}$ to $2,132 \mathrm{~nm}$ at $70^{\circ} \mathrm{C}$. To study micelle formation, $0.01 \%, 0.1 \%$, and $0.5 \%$ DDM solutions without protein were analyzed with DLS. The results showed that the Z-ave of particles increased considerably in the $0.5 \%$ DDM solution when increasing the temperature (Table 2); while at lower concentrations of DDM, the Z-ave did not change significantly. It seems that DDM starts forming micelles at concentrations higher than $0.5 \%$. The formation of micelles could negatively affect the anti-aggregation potential of DDM.

\section{Thermal unfolding}

Thermal unfolding of IFN- $\beta-1 \mathrm{~b}$ was analyzed by both fluorescence and CD spectroscopy. The tryptophan residues of IFN- $\beta-1 \mathrm{~b}$ were excited at a wavelength of $295 \mathrm{~nm}$, and a typical maximum emission was detected around $340 \mathrm{~nm}$ (Fig. 2) (Karpusas and others 1998; Runkel and others 2000). A comparison of the fluorescence emission peaks of IFN- $\beta-1 \mathrm{~b}$ in the absence (Fig. 2A) or presence (Fig. 2B) of $0.1 \% \mathrm{DDM}$ at $25^{\circ} \mathrm{C}-70^{\circ} \mathrm{C}$ showed a $6-14 \mathrm{~nm}$ red shift. The fluorescence spectrum intensity also increased $42 \%-78 \%$ in

Table 2. Dynamic Light Scattering of Different Concentrations of Dodecylmaltoside and Sodium Dodecyl Sulfate

Without INTERFERON BeTA-1B AT $25^{\circ} \mathrm{C}$ AND $70^{\circ} \mathrm{C}$

\begin{tabular}{lccccc}
\hline & \multicolumn{2}{c}{$25^{\circ} \mathrm{C}$} & & \multicolumn{2}{c}{$75^{\circ} \mathrm{C}$} \\
\cline { 2 - 3 } \cline { 6 - 7 } Temperature & Z-ave $(\mathrm{nm})$ & $P D I$ & & Z-ave $(\mathrm{nm})$ & $P D I$ \\
\hline $0.5 \%$ DDM & 11 & 0.26 & & 194 & 0.19 \\
$0.1 \%$ DDM & 10 & 0.13 & & 11 & 0.29 \\
$0.01 \%$ DDM & 9 & 0.14 & & 11 & 0.19 \\
$0.1 \%$ SDS & 10 & 0.24 & & 19 & 0.27 \\
\hline
\end{tabular}

comparison with IFN- $\beta-1 \mathrm{~b}$ in the absence of surfactant over the temperature range tested. The melting temperatures $\left(T_{m}\right)$ of protein in the presence of different concentrations of DDM were computed by fitting fluorescence spectroscopy data using equation 3 . A value of $42^{\circ} \mathrm{C}$ was obtained for the $T_{m}$ of IFN- $\beta-1 \mathrm{~b}$ in the absence of surfactant. While $0.01 \%$ and $0.5 \%$ DDM had no significant effect on the $T_{m}, 0.1 \%$ DDM increased it by $8^{\circ} \mathrm{C}$ (Fig. 3). The enhanced intensity of the fluorescence spectrum suggests that in the presence of $0.1 \% \mathrm{DDM}$, the tryptophan residues are more accessible and less quenched due to the lower degree of aggregation (Chen and Barkley 1998; Fan and others 2005; Qiu and others 2008; Van Beers and others 2010). At higher temperatures, DDM protected the protein structure against denaturation.

Far-UV CD spectra of IFN- $\beta-1 b$ in the absence or presence of different concentrations of DDM or SDS were obtained at $25^{\circ} \mathrm{C}, 40^{\circ} \mathrm{C}$, and $70^{\circ} \mathrm{C}$ (Fig. 4). A negative shift in ellipticity at $222 \mathrm{~nm}$ reflects more $\alpha$-helix in the secondary structure of IFN- $\beta-1 b$ (Fazeli and others 2013). The intensity of the spectrum increased by adding DDM or SDS to the IFN- $\beta-1 \mathrm{~b}$ solution. $0.1 \%$ DDM had the most effect on preserving the helical structure of the protein (Fig. 4). The results showed that the presence of $0.1 \%$ DDM leads to a $62 \%$ increase and a $25 \%$ decrease in $\alpha$-helical and $\beta$-sheet structures, respectively, at $25^{\circ} \mathrm{C}$.

\section{Antiviral activity}

As described earlier, IFN- $\beta-1 b$ tends to form aggregates with low in vitro biological activity when no stabilizing additive is present in solution. IFN- $\beta-1 b$ in its pharmaceutical form (Betaferon and Extavia) is formulated (after reconstitution of the lyophilized drug product) with $12.5 \mathrm{mg} / \mathrm{mL}$ human albumin to protect the protein. If DDM is to be used as a potential anti-aggregation agent for IFN- $\beta-1 b$, its effect on the biological activity of the protein should be determined. Therefore, desalted IFN- $\beta-1 \mathrm{~b}$ samples were formulated with $12.5 \mathrm{mg} / \mathrm{mL}$ human albumin or $0.1 \% \mathrm{DDM}$, and their activities were determined using an in vitro antiviral assay. Compared with the NIBSC IFN- $\beta-1 \mathrm{~b}$ standard, potency values of $103 \% \pm$ $5 \%$ and $105 \% \pm 5 \%$ were obtained for samples formulated with albumin and DDM, respectively, while desalted samples in the absence of additives had a potency of $23 \% \pm 3 \%$.

\section{Discussion}

Key in the downstream processing of $\operatorname{rhIFN}-\beta-1 \mathrm{~b}$ is the stabilization of the extracted protein. The addition of $0.1 \%$ DDM to aggregated IFN- $\beta-1 \mathrm{~b}$ led to the dissolution of the aggregates and a $62 \%$ increase in $\alpha$-helical structure at $25^{\circ} \mathrm{C}$. 
FIG. 2. Fluorescence emission spectra of IFN- $\beta-1 b$ when increasing the temperature from $25^{\circ} \mathrm{C}$ to $70^{\circ} \mathrm{C}$ in the presence of (A) no surfactant (control); (B) $0.1 \%$ DDM; and (C) $0.1 \%$ SDS.
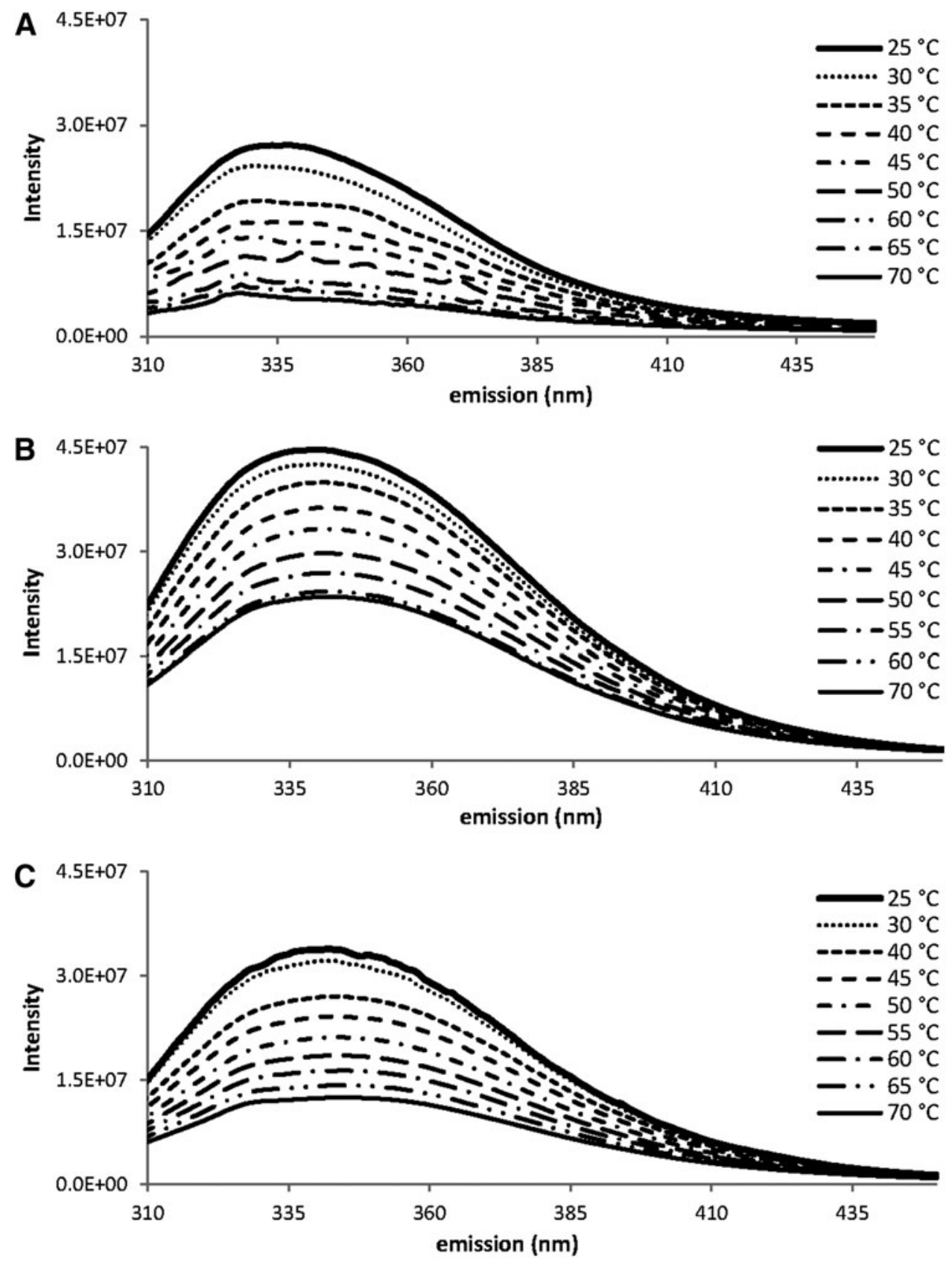

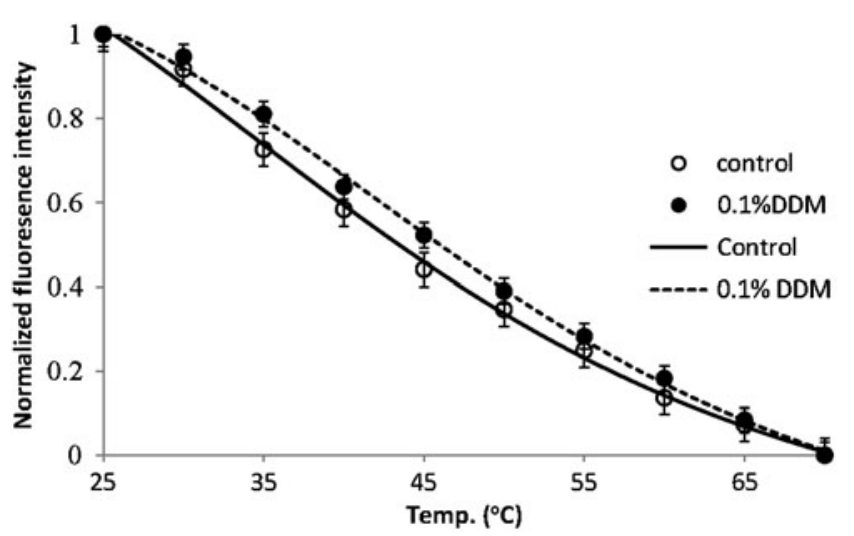

FIG. 3. Effect of $0.1 \%$ DDM on melting temperature $\left(T_{m}\right)$ of IFN- $\beta-1 b$. Lines are the best fit of experimental data using equation 3 . $\mathrm{R}^{2}>0.99, \chi^{2}<0.001$.
Thermodynamic analysis showed that DDM increased stability and did not interfere with the in vitro biological activity of the protein. In the presence of $0.1 \%$ DDM, IFN- $\beta-1 b$ showed the lowest mean size by DLS and a thermo-stability that protects the protein from aggregation at an increasing temperature. In addition, UV spectroscopy confirmed the reduction in aggregate formation. The $T_{m}$ of IFN- $\beta-1 \mathrm{~b}$ is elevated in the presence of $0.1 \%$ of DDM, demonstrating an improvement in its stability (Pace and Shaw 2000; Kaushik and Bhat 2003).

Surfactants can bind to proteins by a combination of electrostatic and hydrophobic interactions (Subramanian and others 1986). The addition of SDS (anionic surfactant) to a protein solution results in the induction of protein denaturation by changing the protein conformation. SDS is a long-chain hydrocarbon that is highly negatively charged. There are 2 parts of the molecule, a hydrophilic, negatively 

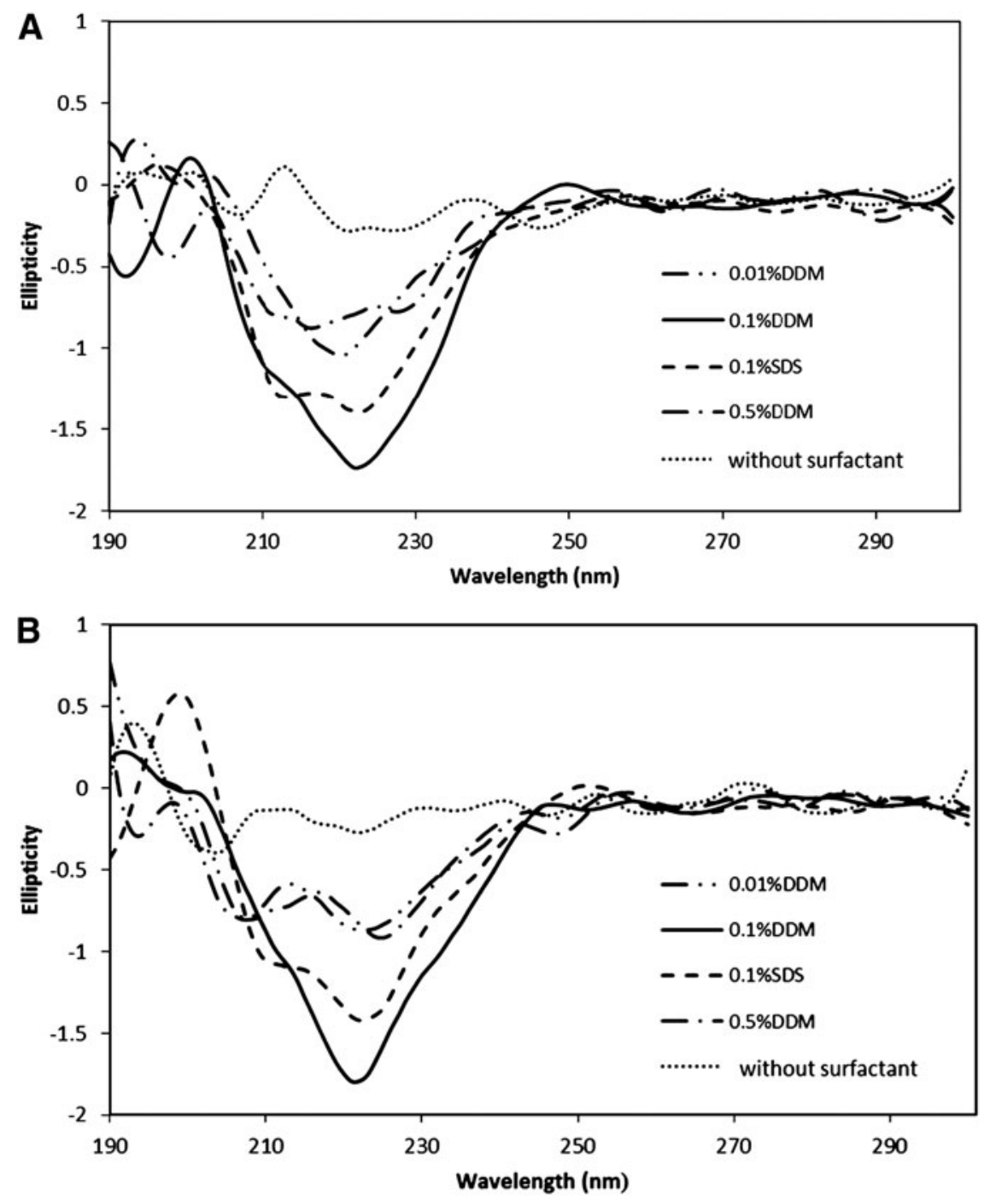

FIG. 4. Far-UV circular dichroism spectrum of IFN- $\beta-1 \mathrm{~b}$ formulated in the absence or presence of different concentrations of DDM and SDS. Spectra were obtained at (A) $25^{\circ} \mathrm{C}$; (B) $40^{\circ} \mathrm{C}$; and $(\mathbf{C}) 70^{\circ} \mathrm{C}$.

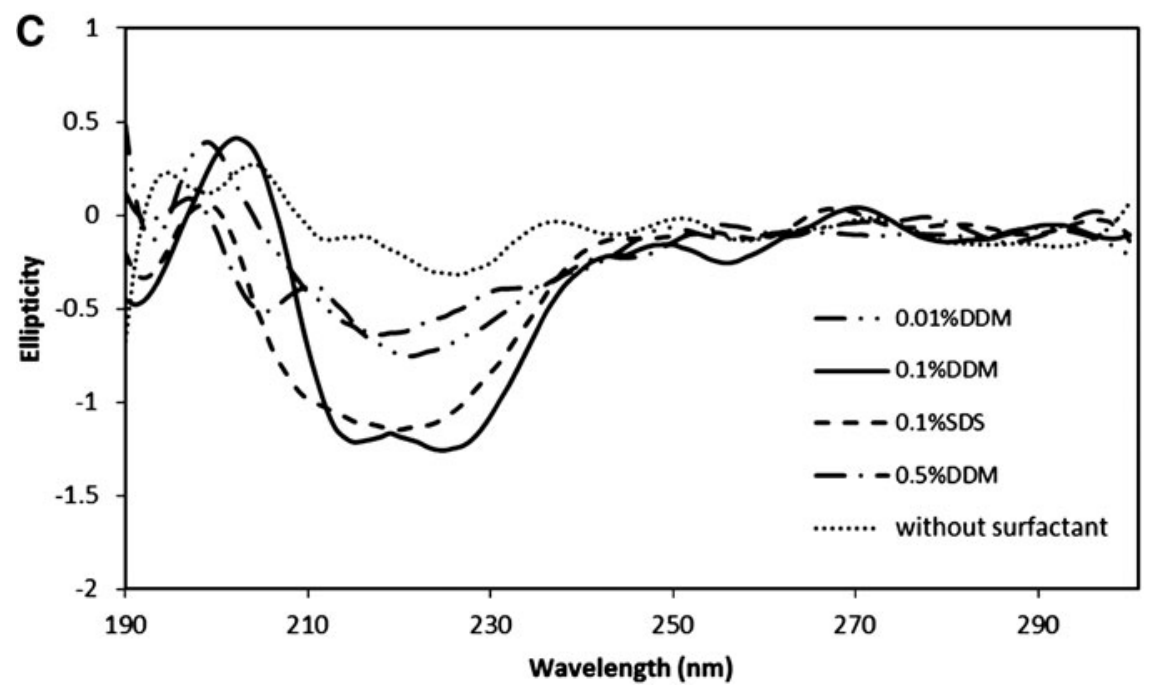

charged head group, and a long hydrophobic chain (tail). At concentrations above $0.1 \%$, SDS forms micelles in which the charged "head" is exposed to solvent and the hydrophobic tail is buried and the protein becomes denatured. At concentrations below $0.1 \%$, there is generally a minimal effect on proteins (Jacqueline and Tanfordt 1970; Bhuyan
2009). In contrast, the absorption of DDM (non-ionic surfactant that has no charge on the head group) on hydrophobic surfaces of IFN- $\beta$-1b covers the protein surface. The surface then becomes hydrophilic and non-ionic due to the enhancement of solubility while preserving protein structures (Zhang and others 1997; Attwood and Florence 2008). 
The results show that increasing DDM concentration beyond $0.1 \%$ is not necessarily beneficial. While the conformational stability of IFN- $\beta-1 \mathrm{~b}$ increased considerably by adding $0.1 \%$ DDM to the solution, $0.5 \%$ DDM did not improve the protein's stability further, possibly due to the DDM becoming less soluble with increasing temperature (Attwood and Florence 2008). The solubilization capacity of a non-ionic surfactant usually decreases with increasing temperature (Attwood and Florence 2008). In the current study, this phenomenon was observed at a concentration of 0.5\% DDM using DLS (Table 2).

Indeed, DDM forms larger micelles at a concentration of $0.5 \%$ in a temperature-sensitive manner (Table 2) with no detectable large size micelles at lower concentrations (Knudsen and Hubbell 1978; De Grip and Bovee-Geurts 1979).

Furthermore, SDS is a toxic surfactant that results in irreversible aggregation, and it needs to be eliminated during pharmaceutical manufacturing, possibly resulting in higher production costs. By contrast, DDM is a nontoxic, nonmutagenic, and non-irritating (Environmental Protection Agency 2005) surfactant (Weber and Benning 1984), and it has been used in the formulation of peptides (Tirumalasetty and Eley 2005).

Finally, the anti-aggregation effect of DDM prevented the loss of biological activity in the formulated IFN- $\beta-1 \mathrm{~b}$ solution. We believe that DDM could be an alternative for human albumin in the formulation of IFN- $\beta-1 b$. While human albumin has some drawbacks that have resulted in the search for albumin-free formulations (Shirley and others 2008), DDM seems to be a safer pharmaceutical adjuvant. Additional studies are planned to investigate this possibility.

\section{Acknowledgments}

This research was supported financially by the Ministry of Science, Research, and Technology of Iran. The authors thank Zistdaru Danesh Co. Ltd. for kindly providing IFN- $\beta$ 1b drug substance. Mazda Radmalekshahi and Andhyk Halim are acknowledged for their valuable suggestions and discussion.

\section{Author Disclosure Statement}

No competing financial interests exist.

\section{References}

Ahsan F, Arnold J, Meezan E, Pillion DJ. 2001. Enhanced bioavailability of calcitonin formulated with alkylglycosides following nasal and ocular administration in rats. Pharm Res 18(12):1742-1746.

Attwood D, Florence AT. 2008. Surfactants. J Pharm Tech Res Ma 4:43-62.

Bhuyan AK. 2009. On the mechanism of SDS-induced protein denaturation. Biopolymers 93(2):186-199.

Chen Y, Barkley MD. 1998. Toward understanding tryptophan fluorescence in proteins. Biochemistry 37:9976-9982.

De Grip WJ, Bovee-Geurts PHM. 1979. Synthesis and properties of alkylglucosides with mild detergent action: improved synthesis and purification of $\beta$-1-octyl-, -nonyl-, and -decyl-glucose. Synthesis of $\beta$-1-undecylglucose and $\beta$-1-dodecylmaltose. Chem Phys Lipids 23:321-325.

Demeester J, de Smedt SS, Sanders NN, Haustraete J. 2005. Light Scattering. In: Jiskoot W, Crommelin DJA, eds. Methods for Structural Analysis of Protein Pharmaceuticals, vol. III. Arlington: AAPS, pp 245-275.

De Vries MK, Brouwer E, van der Horst-Bruinsma IE, Spoorenberg A, van Denderen JC, Jamnitski A, Nurmohamed MT, Dijkmans BA, Aarden LA, Wolbink GJ. 2009. Decreased clinical response to adalimumab in ankylosing spondylitis is associated with antibody formation. Ann Rheum Dis 68: 1787-1788.

Fan H, Ralston J, Dibiase M, Faulkner E, Middaugh CR. 2005. Solution behavior of IFN beta-1a: an empirical phase diagram based approach. J Pharm Sci 94:1893-1911.

Fazeli A, Shojaosadati SA, Fazeli MR, Khalifeh K, Ariaeenejad S, Moosavi-Movahedi AA. 2013. The role of trehalose for metastable state and functional form of recombinant interferon beta-1b. J Biotechnol 163:318-324.

Frokjaer S, Otzen DE. 2005. Protein drug stability: a formulation challenge. Nat Rev Drug Discov 4:298-306.

Jacqueline AR, Tanfordt C. 1970. Binding of dodecyl sulfate to proteins at high binding ratios. Possible implications for the state of proteins in biological membranes. Proc Natl Acad Sci U S A 66(3):1002-1003.

Karpusas M, Nolte M, Benton CB, Meier W, Lipscomb WN, Goelz S. 1997. The crystal structure of human interferon-beta at 2.2-Å resolution. Proc Natl Acad Sci U S A 94:11813-11818.

Karpusas M, Whitty A, Runkel L, Hochman P. 1998. The structure of human interferon- $\beta$ : implications for activity. Cell Mol Life Sci 54:1203-1216.

Kaushik JK, Bhat R. 2003. Why is Trehalose an exceptional protein stabilizer. J Biol Chem 278:26458-26465.

Knudsen P, Hubbell WL. 1978. Stability of rhodopsin in detergent solutions. Member. Biochemistry 1:297-322.

Kueltzo LA, Middaugh CR. 2005. Ultraviolet absorption spectroscopy. In: Jiskoot W, Crommelin DJA, eds. Methods for Structural Analysis of Protein Pharmaceuticals, vol. III. Arlington: AAPS, pp 1-25.

Lopez O, Cocera M, Coderch L, Parra JL, de la Maza A. 2002. Dodecyl maltoside as a solubilizing agent of stratum corneum lipid liposomes. Colloid Polym Sci 280:352-357.

Maggio ET. 2008. Stabilizing alkylglycosides compositions and methods thereof. US Patent 7:522-542.

Maggio ET. 2010. Use of excipients to control aggregation in peptide and protein formulations. J Excip Food Chem 1(2): 40-49.

Maggio ET. 2012. Polysorbates, peroxides, protein aggregation, and immunogenicity - a growing concern. J Excip Food Chem 3(2):45-53.

Marrakchi S, Maibach HI. 2006. Sodium lauryl sulfate-induced irritation in the human face: regional and age-related differences. Skin Pharmacol Physiol 19(3):177-180.

Pace CN, Shaw KL. 2000. Linear extrapolation method of analyzing solvent dena- turation curves. Proteins Suppl.4:1-7.

Philo JS. 2009. A critical review of methods for size characterization of non-particulate protein aggregates. Curr Pharm Biotech 10:359-372.

Pillion DJ, Ahsan F, Arnold JJ, Balusubramanian BM, Piraner O, Meezan E. 2002. Synthetic long-chain alkyl maltosides and alkyl sucrose esters as enhancers of nasal insulin absorption. J Pharm Sci 91(6):1456-1462.

Pillion DJ, Atchison JA, Gargiulo C, Wang RX, Wang P, Meezan E. 1994. Insulin delivery in nosedrops: new formulations containing alkylglycosides. Endocrinology 135(6):2386-2391. Pillion DJ, Wang P, Yorks J, Mccann P, Meezan E. 1995. Systemic absorption of insulin and glucagon applied topically to the eyes of rats and a diabetic dog. J Ocul Pharmacol Ther 11(3):283-295. 
Qiu W, Li T, Zhang L, Yang Y, Kao YT, Wang L, et al. 2008. Ultrafast quenching of tryptophan fluorescence in proteins: interresidue and intrahelical electron transfer. Chem Phys Letters 350:154-164.

Rifkin RF, Maggio ET, Dike S, Kerr DA, Levy M. 2011. nDodecyl- $\beta$-D-maltoside inhibits aggregation of human interferon- $\beta-1 b$ and reduces its immunogenicity. J Neuroimmune Pharmacol 6:158-162.

Rossi L. 2005. Environmental protection agency. Alkyl (C10C16) polyglycosides; exemptions from the requirement of a tolerance. 40 CFR Part 180. 70 (177):54281-54286.

Runkel L, deDios C, Karpusas M, Betzenhauser M, Muldowney C, Zafari M, et al. 2000. Systematic mutational mapping of sites on human interferon-beta-1a that are important for receptor binding and functional activity. Biochemistry 39:2538-2551.

Runkel L, Meier W, Pepinsky RB, Karpusas M, Whitty A, Kimball K, Brickelmaier M, Muldowney C, Jones W, Goelz SE. 1998. Structural and functional differences between glycosylated and non-glycoslated forms of human interferon beta (IFN-beta). Pharm Res15:641-649.

Schellekens H. 2002. Immunogenicity of therapeutic proteins: clinical implications and future prospects. Clin Ther 24: 1720-1740.

Seddon AM, Curnow P, Booth PJ. 2004. Membrane proteins, lipids and detergents: not just a soap opera. Biochim Biophys Acta 1666:105-117.

Shirley BA, Babuka S, Chen BL, Hora M, Choe M, Teller M. 2008. HSA-free formulations of interferon-beta. Patent No. US 7,399,463 B2.

Siano DB, Metzler DE. 1969. Band shapes of electronic spectra of complex molecules. J Chem Phys 51(5):1856.

Steinhardt J, Reynolds JA. 1969. In Multiple Equilibria in Proteins. New York: Academic Press, p 234.
Stubbs GW, Smith HG, Litman BJ. 1976. Alkyl glucosides as effective solubilizing agents for bovine rhodopsin. A comparison with several commonly used detergents. Biochim Biophys Acta 426:46-56.

Subramanian M, Sephardi BS, Venkatappa MP. 1986. Interaction of proteins with detergents: binding of cationic detergents with lysozyme. J Biosci 10(3):359-371.

Tirumalasetty PP, Eley JG. 2005. Evaluation of dodecylmaltoside as a permeability enhancer for insulin using human carcinoma cells. J Pharm Sci 94(2):246-255.

Van Beers MMC, Sauerborn M, Gilli F, Brinks V, Schellekens H, Jiskoot M. 2010. Aggregated recombinant human interferon beta induces antibodies but no memory in immunetolerant transgenic mice. Pharm Res 482(27):1812-1824.

Weber N, Benning H. 1984. Metabolism of orally administered alkyl beta-glycosides in the mouse. J Nutr 114:247-254.

Wolbink GJ, Aarden LA, Dijkmans BA. 2009. Dealing with immunogenicity of biologicals: assessment and clinical relevance. Curr Opin Rheumatol 21:211-215.

Zhang L, Somasundaran P, Maltesh C. 1997. Adsorption of ndodecyl- $\beta$-D-maltoside on solids. J Colloid Interface Sci 191:202-208.

Address correspondence to: Mohadeseh Haji-Abdolvahab Department of Pharmaceutical Science Utrecht University Universiteitsweg 99 Utrecht 3584 CG

E-mail: m.hajiabdolvahab@uu.nl

Received 10 December 2013/Accepted 29 April 2014 